brings out some remarkable resemblances. Both patients were young women presenting very much the same general appearance; in both cases there was a local cause for a certain amount of local and constitutional disturbances ; in both a general attack presented the same features I have already described as characteristic of the disease; in both menstruation and mental excitement were factors in the causation; and both patients exhibited certain well-marked idiosyncrasies to particalar drugs. The attacks in both cases were undoubtedly acute. though Iess severe in the one under notice than in that first described.

Rhyl, North Wales.

\section{A CASE OF OSTEOMA OF THE PELVIS, CAUSING DYSTOCIA.}

By J.M. Finzi, M.D., L.R.C.P. Lond., M.R.C.S. Ena., L.S.A.

Apropos of the case of osteoma of the pelvis recorded by Dr. Wallace in THE LANCET of June 16th, the following case which has just occurred in my practice may be of some interest. On June 16th I was called to see a primipara aged twenty-eight years. On vaginal examination I found a large, smooth, globular swelling of stony hardness, projecting into the right anterior portion of the pelvic cavity and giving exactly the impression that it was the fœtal bead. On further examination the fotal head was found presenting apparently in the left occipito-posterior position, above the brim, the os being about the size of half a crown and the membranes unruptured. Vigorous pains having persisted for about two hours without any advance, I with difficulty applied the axis traction forceps (Milne Murray) and continued attempts at delivery with them for about two hours longer without any effect. I therefore decided to perform craniotomy, which I did with the help of my assistant, Mr. Scudamore, and delivered a full-grown child. Strict antiseptic precautions were adopted throughout, and the mother made an uninterrupted recovery without subsequent rise of temperature. On examining the abdomen on the eleventh day after delivery the tumour could be felt from above encroaching considerably on the cavity of the pelvis and extending from half an inch to the right of the symphysis pubis backwards and downwards in a globular form, and perfectly smooth towards the ischial tuberosity. A history of an injury caused by a fall downstairs about the age of fourteen years was elicited, for which she was treated in hospitals for twelve months in bed, and for which weight extension was used during six months of that time; and. moreover, for three years after that she was unable to put her right foot to the ground or to walk without crutches. Pain along the inner side of the right thigh was a marked feature during labour and had frequently been complained of previously.

Sutherland-avenue, $\mathrm{W}$

\section{CASE OF IDIOPATHIC TETANUS ; RECOVERY.}

By Charles Eyre Counsellor, M.D.Californ., L.S.A., PHYSICIAN TO THE ESMERAIDA COUNTX HOSPITAL, STATE OF

$$
\text { TEVADA, U.S.A. }
$$

Aт 8 P.M. on April 24th, 1893, I was called to see a healthy young miner twenty-eight years of age, of sober habits and strong physique, who had been suddenly attacked by spasms. He had been given an emetic of salt-and-water before my arrival. I found him suffering from tonic spasms, evidently of a tetanic nature. Opisthotonos and trismus were well marked; the pupils were dilated, with a look of horror; there was slight risus sardonicus, and the countenance was congested. I promptly administered chloroform on a towel till reiazation set in, and I then gave one drachm of chloral hydrate with half a drachm of bromide of potassium. The patient complained bitterly of the pain during the paroxysms and said he felt as if a hand of iron was slowly strangling him. During the ensuing paroxysms I applied hot moist sponges to the throat, with good effect. Subsequently (about 10.30 P.M.) he went to sleep, and slept all night. On the next day I found him conscious, but very sore. His complexion was still dusky, and there was great pain in the muscles of his neck. The temperature was $101^{\circ} \mathrm{F}$; the pupils were equal and normal ; the skin was moist. He had passed urine freely. He remembered all the details of the attack of the previous evening, and he said that the pain was intense. I gave him fifteen grains of calomel, to be followed in two hours by an ounce of castor oil. The bowels acted freely, black stools being passed. For diet I ordered hot milk only. The paroxysms came on again at noon, and lasted an hour. The symptoms were the same, except that the opisthotonos was replaced by pleurosthotonos. I gave two scruples of chloral hydrate with half a drachm of bromide of potassium, and he slept during the rest of the day, awakening only to micturate and to drink some milk. I repeated the chloral hydrate at bedtime, and again during the night. On the 26th I found that he had passed a good night, but had had slight spasms at 6 A.M. Another dose of the chloral hydrate had sent him to sleep again. I now gave him half an ounce of castor oil, and he passed natural stools. The temperature was normal. I ordered twenty grains of chloral hydrate with twenty grains of bromide of potassium, to be given every time he woke up. On the 27th the patient looked better, having slept well. At 11 A.M. he had strong carpopedal contractions, also trismus. I ordered the chloral bycrate to be continued. On the 28 th the patient com. plained of acute frontal neuralgia. I gave him ten grains of bisulphate of quinine, which afforded relief. The bowels acted naturally. He still took the hot milk freely. There were several slight twitchings during the day, but no marked spasms. He continued to take the chloral hydrate and bromide of potassium in fifteen-grain doses. On the 29th the headache had gone, but the muscles of the neck and jaw felt very sore. I ordered him massage with warm olive oil. The appetite improving, I gave chicken and rice broth in addition to the milk. On the $30 t \mathrm{~h}$ the patient felt "first rate." I allowed him to sit up for a little while in a chair. On May 1st he was discharged cured, and he has since resumed his work.

In this case I could find no canse for the attack either from strychnine poisoning or from trauma. A few days before the attack he had taken violent and unaccustomed exercise on the parallel bars in the gymnasium, and on the next day he had felt very stiff in the muscles of his neck and shoulders. The rationale of my treatment was simply to keep the patient under the influence of chloral bydrate till the disease wore itself out. In all, he took one ounce of chloral hydrate, commencing with the heroic dose of one drachm. The patient was perfectly conscious during the attacks and suffered acutely. The first symptoms were felt in the muscles of the neck and jaw. I believe I am justified in assuming this to be a case of idiopathic tetanus and not tetany, and also in disregarding strychnine poisoning or hysteria by my knowledge of the patient, his surroundings, and his habits. Nevada, U.S.A.

\section{A Aftirtor}

\author{
or
}

\section{H O S P T A L P R A C T I CE。 BRITISH AND FOREIGN.}

Nulla autem est alia pro certo noscendi via, nisi quamplurimas et morborum et dissectionum historias, tum aliormn tum proprias collectas habere, et inter se comparare.-Morgagi De Sed. et Caus. Morb., lib. iv. Procmium.

\section{LONDON HOSPITAL.}

TWO CASES OF CAESAREAN SECTION.

(Under the care of Dr. HERMAN.)

IN The LANCET of Dec. 16th and 23rd, 1893, we reported some cases of Cæsarean section performed at the London Hospital by Dr. Herman. Those reports completed the publication of the cases of that operation performed by Dr. Herman up to that date. We now report two more cases since performed in the same hospital.

CASE 1. Fibroid blocking pelvic carity; Cesarean section after twenty hours' labour; living child; death of mother from peritonitis. (Reported by Dr. David Brown, resident accoucheur, and Mr. H. W. Beedham, clinical clerk.)-A woman thirty-three years of age was admitted to the London Hospital on Jan. 26th, 1894, at 10 P.M. She had had one 